University of Nebraska - Lincoln

DigitalCommons@University of Nebraska - Lincoln

June 1990

\title{
Wetlands Provisions in the 1985 and 1990 Farm Bills
}

\author{
F. Gregory Hayden \\ University of Nebraska-Lincoln, ghayden1@unl.edu
}

Follow this and additional works at: https://digitalcommons.unl.edu/econfacpub

Part of the Economics Commons

Hayden, F. Gregory, "Wetlands Provisions in the 1985 and 1990 Farm Bills" (1990). Economics Department Faculty Publications. 12.

https://digitalcommons.unl.edu/econfacpub/12

This Article is brought to you for free and open access by the Economics Department at DigitalCommons@University of Nebraska - Lincoln. It has been accepted for inclusion in Economics Department Faculty Publications by an authorized administrator of DigitalCommons@University of Nebraska - Lincoln. 


\section{Wetlands Provisions in the 1985 and 1990 Farm Bills}

\section{F. Gregory Hayden}

In 1984, my national agricultural policy article surprised some readers because its first concern was with policy regarding the natural environment [Hayden 1984]. Others thought it contained the policy agenda that agricultural policymakers could expect in the future. The future came more quickly than most expected when the 1985 Farm Bill (Food Security Act) included provisions to limit harmful impacts of the agriculture industry on the environment. The purpose of this article is to explore the importance, success, and future of the Swampbuster provision that was intended to protect wetlands in the United States from further agricultural destruction.

\section{Context}

Context is emphasized in all science-especially in institutional economics because the policy context is inherent in all institutional inquiry. Thus a brief indication of context is in order. A thumbnail sketch of the paradigmatic context of this article is shown in the column labeled "Eco-Development" in Table 1, below.

The original swampbuster provisions of the 1985 Farm Bill were conceived from the "Eco-Development," view as will most policies dealing

The author is Professor of Economics, Uniwersity of Nebraska-Lincoin. This article was presented at the annual meeting of the Association for Evolutionary Economics, 27-30 December 1989, Atlanta, Georgia. 


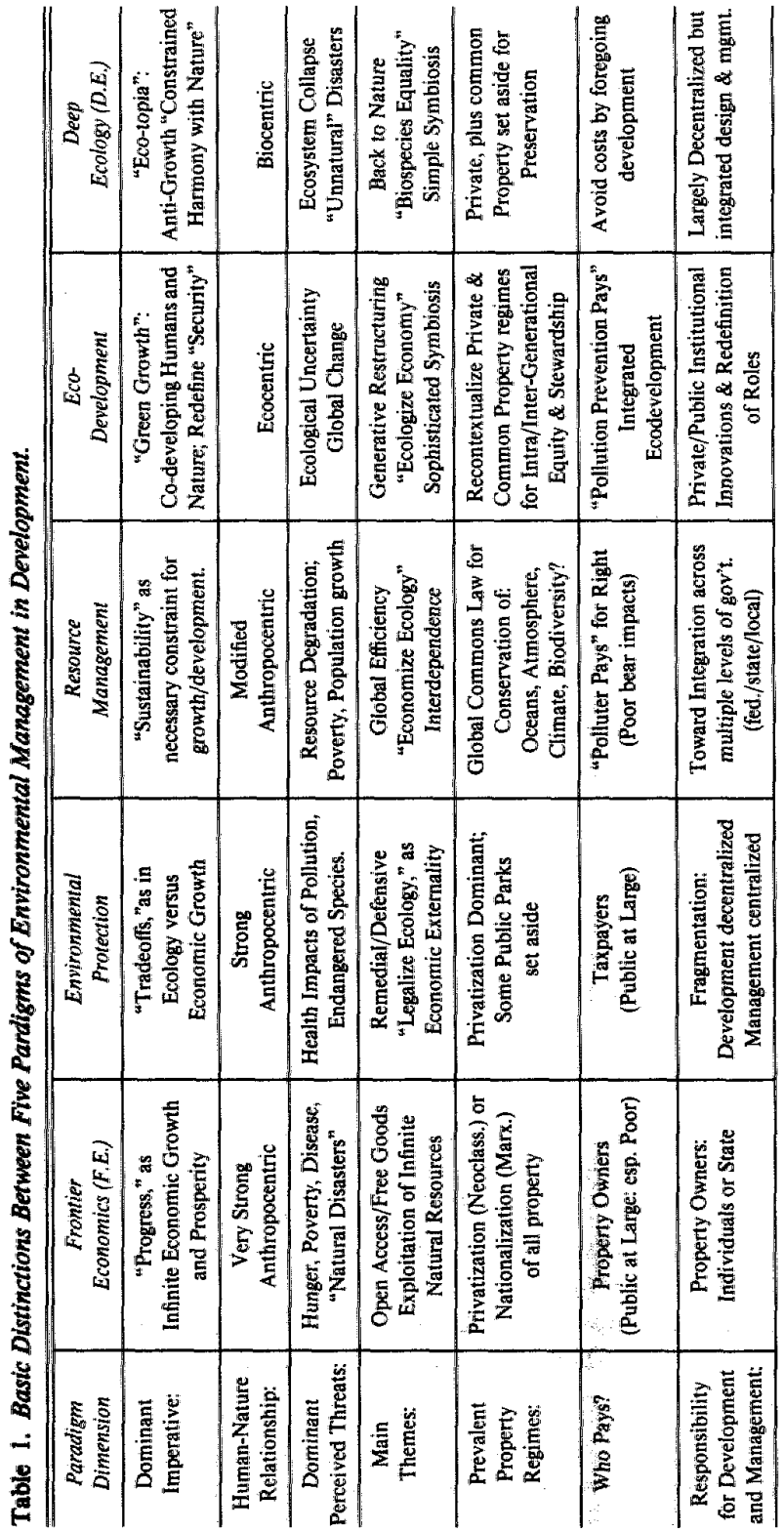




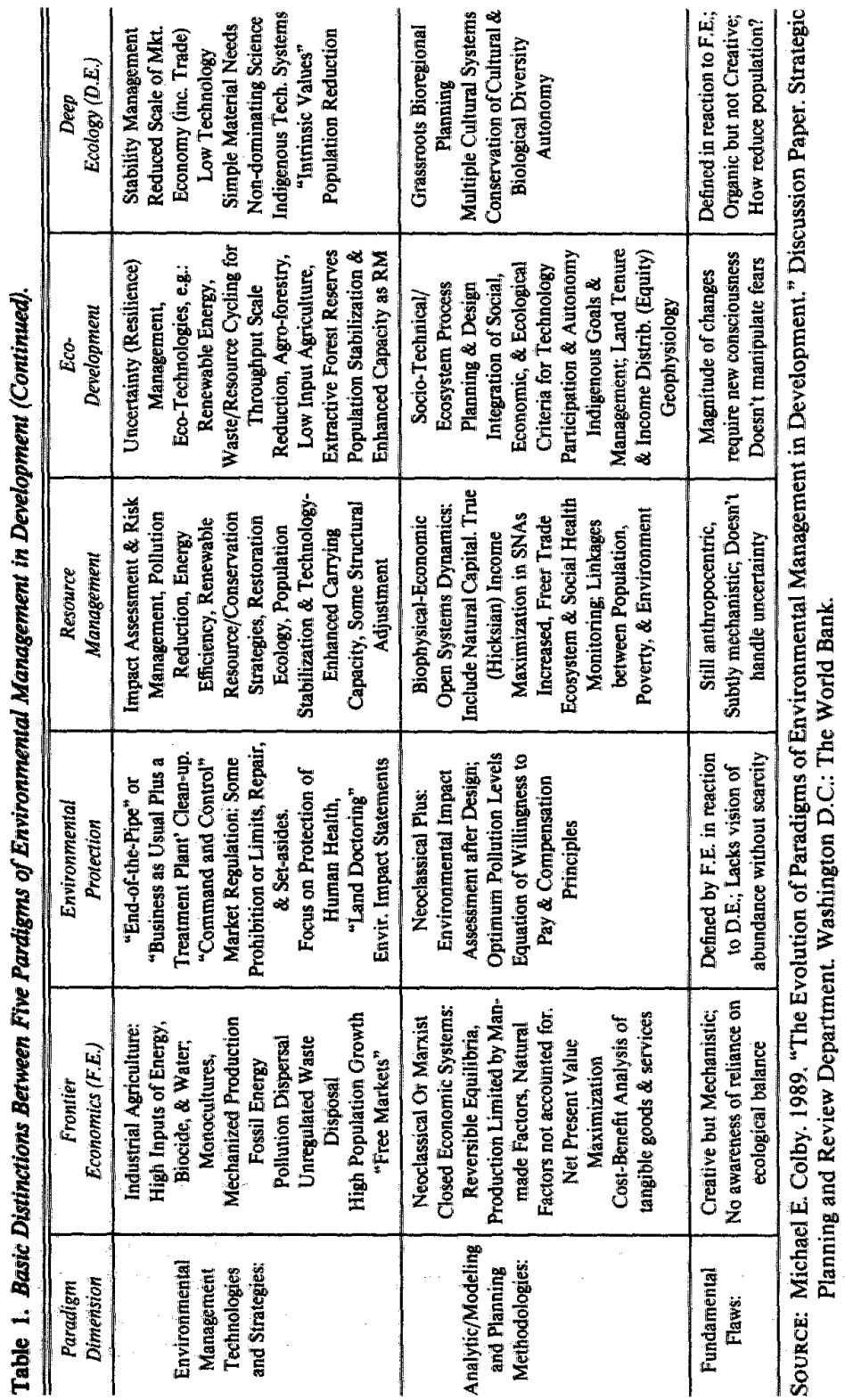


with the ecological/socioeconomic interface in the future. The agricultural context to which policy alternatives in this article are intended to conform is the broad version of low input sustainable agriculture (LISA). The fiscal context is one of a large federal deficit, which inhibits many of the efforts needed to protect wetlands.

\section{Wetlands are Valuable}

The benefits of wetlands are now recognized internationally. Wetlands are one of our most valuable resources and are often referred to as the nursery for much of life. In addition, they are the source of nutrition and habitat for much of that life. Wetlands are the world's most productive acres for nutrition in the food web, and are particularly efficient converters of solar energy. The plants convert sunlight into plant material and produce oxygen as a byproduct. Soil, water, plants, animals, and humans exist in an interdependent system called a food web, which is a series of related food chains.

The benefits of wetlands as usually recognized include: (1) ecosystem function, (2) fish and shellfish habitat, (3) waterfowl and other bird habitat, (4) furbearer and other wildlife habitat, (5) pollution filtration, (6) sediment removal, (7) heavy metal removal, (8) oxygen production, (9) nutrient production and recycling, (10) chemical pollution absorption, (11) aquatic production, (12) microclimate regulation, (13) world climate (ozone layer) regulation, (14) flood control, (15) wave damage protection, (16) erosion control, (17) groundwater recharge and water supply, (18) energy source, (19) livestock grazing, (20) fishing, (21) fertilizer industry, (22) hunting and trapping, (23) recreation, (24) preservation of genetic inventory, (25) aesthetics, and (26) scientific research.

\section{Wetland Losses}

When Europeans arrived in the United States, there were approximately 215 million acres of wetlands in what are now the forty-eight coterminous states. By the mid-1970s, 46 percent of the original wetlands' acreage remained-only 99 million acres. "The average rate of wetland loss from the mid-50s to the mid-70s was 458,000 acres per year" [Tiner 1984, p. 31].

Early in U.S. history, as would be expected, agricultural efforts were responsible for about one hundred percent of wetland destruction. "Agricultural development involving drainage was responsible for $87 \%$ of recent national wetland losses, while urban development and other de- 
velopment caused only $8 \%$ and $5 \%$ of the losses respectively. Agriculture had the greatest impact on forested wetlands and emergent wetlands [Tiner 1984, pp. 31-32]. Even in areas of rapidly growing urban populations, agriculture conversion is still the main source of loss. "Only about 30 percent of wetland loss in rapidly growing Southeastern counties is due to direct conversion for urban land uses. Wetlands converted to agriculture and forestry account for 65 to 70 percent of gross losses" [Heimlich and Vesterby 1989, p. 169].

The diversity of the wetlands cannot be overemphasized. Similarly there are regional differences in the rate of conversion. "In North and South Dakota, pothole wetlands originally covered 7 million acres. Today, only slightly more than 3 million acres remain" [Tiner 1984, p. 42]. "Prairie potholes are among the most important and most threatened ecosystems in the United States. They are prime nesting grounds for many species of North American waterfowl. Up to 50 percent of the United States production of migratory waterfowl is raised in the United States portion of the prairies in some years" [Goldstein et. al. 1988, pp. 79-80]. The loss of the prairie potholes has had a prominent impact on the duck population. In 1985 "the mallard population was at an all-time low of 5.5 million, a 47 percent decline from the first census figures in 1955. The sharpest decline occurred in the pintail population, which was down 69 percent from 1955 [Heimlich and Langner $1986 \mathrm{~b}$, p. 17]. The mallard and pintail are today's buffalo.

Over 90 percent of the Nebraska Rainwater Basin wetlands have been converted for agricultural uses and "Iowa has lost more than $99 \%$ of its natural marshes" [Tiner 1984, p. 42]. The Rainwater Basin is a migratory stop and staging area for 2.5 million ducks and geese. Because of crowded conditions there are regular outbreaks of avian cholera among the waterfowl.

Wetlands are also damaged by agricultural activities other than drainage. "Pesticides and fertilizers for example, can contaminate runoff water that makes its way into a wetland" [Zinn et. al. 1989, p. CRS-4]. Recent research by the U.S. Fish and Wildlife Service (USFWS) indicates that agricultural pesticides are killing large numbers of wild ducklings in the prairie pothole region of the Northern United States and Canada. The insecticides "are either acutely toxic to waterfowl, to the aquatic invertebrates on which adult and juvenile waterfowl depend for food, or both" [Lorenz 1989, p. 1].

The agricultural drainage in the Everglades of Florida have affected the fishing industry and human water supplies. "Freshwater runoff from these areas maintains the salinity balance of coastal estuaries, 
which support 85 percent of off-shore fishery" [Heimlich and Langer 1986 a, p. 233]. Because of the drainage, various problems have been created, "including saltwater intrusion into public water supplies" [Heinlich and Langer 1986a, p. 233].

\section{Failure of 1985 Swampbuster Provisions}

To address the urgency of wetland protection, the 1985 Farm Bill included the Swampbuster provisions, which make farmers who drain and plant wetland areas after December 23, 1985 ineligible for many federal farm programs. ${ }^{1}$ In addition, in 1986, eligibility for the Conservation Reserve Program, which allows producers to receive annual payments to retire land from production, was expanded to include wetland areas. The loss of program benefits is not limited to crops grown on the converted wetland but applies to the farmer's entire farm. Other details of the Swampbuster provisions will be articulated below in conjunction with recommendations for reform.

Swampbuster, although a step in the right direction, has encountered numerous difficulties for a number of reasons. It did not forbid the conversion of wetlands or encourage restoration. It ignored the need to establish new property entitlements because the government did not want to increase federal expenditures. This placed the burden on the farmers, while at the same time providing them with an incentive to drain wetlands more rapidly. Swampbuster management has been poor at best and compliance unequally applied. It has not been well monitored, nor has it been implemented successfully to bring about desired consequences. Thus serious consideration needs to be given to its reform.

\section{Recommendations for the 1990 Swampbuster Provisions}

The 1990 Farm Bill will provide an opportunity to reform and extend Swampbuster. Secretary of Agriculture Clayton Yuetter has complained that environmental groups are more prepared than any other group for the upcoming debate. In anticipation of that debate, suggestions with regard to Swampbuster and wetlands are provided below.

The diverse variety of wetlands-oceanic coastal, North Dakota prairie potholes, lower Mississippi alluvial plain, Nebraska sandhillsmakes it difficult to make blanket statements about wetlands, whether it is with regard to the hydrologic characteristics, the financial benefits of conversion, or the impact of alternative policies. This means that 
for any policy approach to wetlands to be successful there must be a substantial input of close monitoring and micromanagement.

\section{Forbid Conversion}

The 1990 Farm Bill should forbid drainage or other conversion of wetlands without regard to whether the farmer plants crops in the wetland or participates in federal farm programs. Under the 1985 Swampbuster, a wetland can be converted with no penalty. There is a penalty assessed only if an annual crop is planted on the land. Farmers often do not convert wetlands in order to profit from crops grown on them. Many of the wetlands that are drained will still fill up long enough after a rain so that crops planted in them are lost in most years. Farmers often ditch wetlands for more rapid drainage of adjoining land or to rid themselves of what they consider a nuisance.

The farmer may drain the wetland and plant it to a crop not disallowed by the program, such as hay. Or he may drain it in a year when earth-moving technology in the area is idle and available to convert the wetland at a bargain price. The farmer can then wait for a year when commodity prices are above the government loan rate, opt out of the federal programs and plant the wetlands. The penalty does not apply unless the farmer converts and then plants a disallowed crop. Thus 1985 Swampbuster is flawed in its enforcement concept.

\section{Property Entitlement Change}

In essence the 1985 Swampbuster amounted to "easement" without compensation to the farmer. The farmer lost the crop base of newly converted wetlands. Historically, many wetlands have been "farmed" so that the farmer could increase the crop base of federally supported programs. In addition, where Swampbuster successfully prevents conversion, the farmer loses acres with conversion potential for additional crops or for additional acres that can be sold at a higher price than wetlands. This is the taking of property entitlements, income, and asset value without compensation. One group, farmers, is being forced to bear the burden of a national public good as private property is converted to common property.

Because the legislation did not begin with compensation for easements, leases, or options to buy wetlands at the time of change of ownership, yet created the loopholes described above, there was great incentive for the farmer to undertake any contemplated drainage. Swampbuster conveyed to the farmer that the nation was likely to pre- 
vent all wetland conversion in the future, and that it would do so by placing the cost on the farmer. This created an incentive to rush into conversion projects before they were completely disallowed and the farmer stuck with de facto taking of land value without compensation.

The 1990 Swampbuster must recognize and compensate for property entitlement changes to prevent future wetland drainage. How this can be accomplished is explained below in the section on restoration.

\section{Enforcement Penality}

If Swampbuster is enforced, the penalty is severe when the farmer converts a wetland and plants a disallowed crop. This is referred to as the "drop dead penalty." It is an all or nothing penalty. Some have argued that "as much as some ASCS [Agriculture Stablization and Conservation Service] county committees would be willing to make the right decision on compliance, they do not have the fortitude to withhold $\$ 50,000$ in benefits from someone who has drained a one-acre wetland" [U.S. Fish and Wildife Service 1988, p. 3]. Recommended changes in the enforcement penalty are threefold.

First, ASCS, as will be outlined below, should not be responsible for making compliance and eligibility decisions.

Second, to effectively stop farmers from planting converted wetlands in years when commodity prices are high and federal subsidies are not needed, the penalty should be extended to include the denial of additional federal programs from which farmers profit, not just commodity programs. It should include: (1) loans from federally guaranteed secondary markets, such as banks and insurance companies, (2) loans from the Farm Credit System, (3) below-cost federal reclamation water, (4) disaster grants and other forms of special drought and emergency relief (by requiring repayment with interest if Swampbuster is violated in the next period of years), and (5) the tax code where farmers must be in compliance with Swampbuster to use cash accounting and accelerated depreciation. It is urgent to preserve wetlands, and if Congress will not forbid conversion outright, then the penalties should be structured so they will be effective in all years irrespective of commodity prices. An alternative would be to assess a monetary fine on the farmer corresponding to the value of the wetland lost, which could be much greater than the penalty suggested here.

Third, the "drop dead penalty" should be changed to allow a progressive return of federal program benefits as the farmer restores the wetland. 


\section{Compliance}

Swampbuster compliance problems are too extensive to cover in this article. However, indicators of noncompliance are that approximately one million acres of wetlands have been lost since 1985, and 1987 was the highest rate of drainage and conversion of any year in U.S. history. Upon the National Wildlife Federation's Freedom of Information Act inquiry, it was found, contrary to published USDA information, that as of April 1989 "there are only 26 producers in the entire United States who have actually lost benefits as a result of a Swampbuster violation which occurred between December 23,1985 and April 15, 1989. The total amount of benefits forfeited by these individuals was a mere $\$ 123,795.42$." [Hair 1989, p. 3]. On the average, this is less than $\$ 5,000$ per farmer, which is an indication that only small farmers are being penalized. Of the nationwide benefits lost, "not a single dollar was withheld from a producer in the Pacific flyway, the gulf coast or the South. In fact, only six states have ever withheld agricultural subsidies as a result of a Swampbuster violation" [Hair 1983, p. 3]. Four changes to improve compliance are as follows:

First, the U.S. Fish and Wildlife Service (USFWS) should replace the ASCS in making decisions with regard to compliance. Under existing Swampbuster, the county ASCS committees make the day-to-day decisions and ultimately determine eligibility for program benefits. The members of these committees do not have the ecological training, the judicial experience, or the beliefs and attitudes consistent with fulfilling the task. Consequently ASCS committees have frequently granted exemptions inconsistent with regulations. Committee members must be resident farmers in the county in which they serve and are elected by other resident farmers. Thus rendering Swampbuster regulation decisions puts the committee members in the position of harming friends and neighbors. Moreover, since most ASCS members do not believe in Swampbuster, they do not want it enforced on their own farms, so they do not want to enforce it on others' farms. In addition the purpose of ASCS is to assist farmers. The purpose of USFWS, on the other hand, is to protect the environment. USFWS is currently the principal investigator of Swampbuster violations and also has the knowledge, the experience working with the technical expertise of other agencies, and the experience with mitigation processes necessary to successfully carry out this compliance role.

Second, compliance can be improved if the rule allowing erroneous decisions to be used as a base for permitting drainage is repealed. Cur- 
rently, if a farmer can get a county committee to make an erroneous decision to allow drainage, the farmer can begin conversion before the appeal process is completed. Even if higher level ASCS officials deny the permit to drain, the farmer is allowed to continue the wetland destruction because an official had already erroneously given permission. This has been used by a local ASCS to override an ASCS Deputy Administrator's ruling in order to allow a Water Resource District to proceed with a project that will drain more than 6,000 acres of prairie wetlands in North Dakota. The USFWS should be funded to provide a thorough education of farmers, including community workshops. Farmers should then be held accountable for knowing the law and abiding by it.

Third, the lengthy and antiquated appeal process should be revised and made consistent with twentieth-century knowledge about such processes. There is an insufficiency of administrative appeals procedures. Although farmers can seek administrative review of adverse decisions, similar rules do not exist for nonfarmers such as the National Wildlife Federation. A farmer's appeal is considered by a different and independent branch of the ASCS than the one that considers the informal nonfarmer's appeal. ASCS regulations prohibit the nonfarmer from participating in the hearing without the consent of the farmer. "Possibly the worst aspect of the present review scheme is that it is unnecessarily lengthy. The ASCS must entertain both formal producers' appeals and informal nonproducers" appeals before it can ultimately resolve a swampbuster issue. Ditch proponents often take advantage of the confusion which attends the review process to initiate construction of a drainage project" [Turrini, Baron, and Nomsen 1989, p. 8].

\section{Restoration}

Many of our agriculture-related natural resource programs establish periods of protection too brief to cause a cumulative improvement. For example the Conservation Reserve Program and Water Bank Program are both ten-year lease programs. When one considers that it took about 400 million years to establish the fragile covering overlaying this planet, it becomes apparent that a sprinkling of ten-year leases will not accomplish restoration. This is especially true for wetlands.

A restoration program to reestablish primary wetlands that are now being farmed needs to be established in the 1990 Farm Bill. In order to finance it, given the current federal deficit problem, the first five or ten years could consist of a lease program, followed by a lump sum payment for a permanent easement at the end of the lease period. The 
saving in deficiency payments and Conservation Reserve Program payments on these restorable wetlands can be used to meet the lease and lump sum payments.

In restoring wetlands, allowances for contiguous uplands need to be included. Wetlands, as an ecosystem, cannot function without uplands. "Without a thrust toward improving uplands, waterfowl recruitment will remain low, and protecting existing wetlands will achieve little progress toward the ... goal to restore waterfowl populations" [Davis 1989 , p. 4].

\section{Easements on Excess Land Inventories}

The federal government is now in possession of an inventory of excess lands on which it foreclosed during the agricultural recession. Permanent easements to protect wetlands should be established on that land before it is sold. This is an opportunity to protect wetlands without any direct expenditure from the federal treasury.

These recommended reforms should allow us to move toward a coevolutionary future with a viable ecosystem and a sustainable agriculture.

\section{Note}

1. The program benefits are: (1) Commodity loans and purchases, (2) Cotton Production Stabilization, (3) Emergency Conservation Program, (4) Emergency Loans, (5) Farm Operating Loans, (6) Farm Ownership Loans, (7) Feed Grain Production Stabilization, (8) Storage Facilities Equipment Loans, (9) Wheat Production Stabilization, (10) National Wool Act Payment, (11) Beekeeper Indemnity Payments, (12) Rice Production Stabilization, (13) Federal Crop Insurance, (14) Soiland Water Loans, and (15) Loans to Indian Tribes and Tribal Corporations.

\section{References}

Baron, Wayne R. 1989. “Current State of Wetland Protection." Paper delivered at Ducks Unlimited International Symposium (8-11 June) Washington, D.C.

Batie, Sandra S. 1988. "Agriculture as the Problem: New Agendas and the New Opportunities." Southern Journal of Agriculture Economics. 20 (December): $1-\mathbb{1} 1$.

Better Understanding of Wetland Benefits Will Help Water Bank and Other Federal Programs Achieve Wetland Preservation Objectives. 1979. PAD-79-10. Washington, D.C.: General Accounting Office.

Convention on Wetlands of International Importance Especially as Waterfowl 
Habitat. U.S. Senate Treaty Document 99-28.

Davis, David G. 1989. "Wetlands Conservation Since 1970: One Observer's Reflections." National Wetlands Newsletter (November-December): 2-4.

Goldstein, Jon H., et al. 1988. The Impact of Federal Programs on Wetlands: Washington D.C.: U.S. Department of Interior.

Hair, Jay D. 1989. Letter to Clayton Yeutter, Secretary of Agriculture. Washington D.C.: National Wildlife Federation (October 13).

Hayden, F. Gregory. 1984. “A Geobased National Agriculture Policy for Rural Community Enhancement, Environmental Vitality, and Income Stabilization" Journal of Economic Issues. 18 (March): 181-221.

Heimlich, Ralph E. 1989, "The Swampbuster Provision: An A Priori Evaluation of Effectiveness" Wetlands: Concerns and Successes (September): 509-21.

Heimlich, Ralph E., and Linda L. Langner. 1986a. "Swampbusting in Perspective." Journal of Soil and Water Conservation 41 (July-August): 219-224.

1986b. Swampbusting: Wetland Conversion and Farm Programs. Economic Report No. 551. Washington D.C.: U.S. Department of Agriculture.

Heimlich, Ralph E., and Marlow Vesterby. 1989. "Conversion of Wetlands to Urban Uses: Evidence from Southeastern Counties" Wetlands: Concerns and Successes, pp. 161-73. Proceedings of a Symposium sponsored by the American Water Resources Association. September.

Lanner, Devorah, Patricia Funk, Marty Strange, and Kristie Thorp. 1989. Unsettled Ground: An Assessment of the 1985 Soil Conservation Provisions and Future Policy Recommendations. Walthill, Neb.: Center for Rural Affairs.

Lorenz, Jack. 1989. "Press Release." Izaak Walton League News (June 13): 1-3.

Lowrance, Richard, Ralph Leonard, and Joseph Sheridan. 1985. "Managing Riparian Ecosystems to Control Nonparent Pollution." Journal of Soil and Water Conservation 40 (January-February): 87-91.

McCullough, Rose and Daniel Weiss. 1985. "An Environmental Look at the 1985 Farm Bill." Journal of Soil and Water Conservation 40 (May-June): 267-270.

Nationall Wildlife Federation/Agricultural Stabilization and Conservation Service. 1989. "Memorandum in Support of Plaintiffs Motion for Preliminary Injunction." Civil Action No. A4-89-067. United States District Court for the District of North Dakota, Northwestern Division.

Robinson, Ann Y. 1987. Saving the Soil and Wildlife: The Promise of the Farm Act's Conservation Title. Arlington, Va.: Izaak Walton League of America.

Swanson, Larry D. 1986. The Profitability of Wetland Drainage in the Rainwater Basin of Nebraska. Kansas City: U.S. Environmental Protection Agency.

Timer, Ralph W. Jr. 1984. Wetlands of the United States: Current Status and Percent Trends. Washington D.C.: U.S. Government Printing Office.

Turrini, Anthony N., Wayne Baron, and David Nomsen. 1988. "Swampbuster Implementation in North Dakota, South Dakota, and Minnesota." Paper presented at 50th Annual Midwest Fish and Wildlife Conference (December).

U.S. Fish and Wildlife Service (USFWS). 1988. "A Resource Evaluation of the 1985 Food Security Act." Nonpublished Paper. Habitat Office, Bismark, North Dakota: U.S. Fish and Wildlife Service. 
Wetlands and their Use and Regulation. 1984. OTA-0-206. Washington D.C.: Office of Technology Assessment.

Zinn, Jeffrey A., M. Lynn Corn, and Claudia Copeland. 1989. Wetlands Protection: Issues in the 101st Congress. Environment and Natural Resources Policy Division, Congressional Research Service. Washington, D.C.: The Library of Congress. 